\title{
An Analysis of Income and Consumption Pattern among Agricultural Labourer Households in Rural Punjab
}

\author{
Sukhdev Singh Sandhu and Jasdeep Singh Toor ${ }^{1}$ \\ Post-graduate Department of Economics, DAV College Sector -10, Chandigarh-160 011, India \\ ${ }^{1}$ Department of Economics Punjabi University, Patiala-147 002, India \\ E-mail: sukhdeveco@gmail.com
}

\begin{abstract}
Pattern of income and consumption is an important parameter to study the economic conditions of people living in any society. The present analysis is based upon primary data which collected from three different agro-climate regions of Punjab (South-west, Central plain and Shivalik foot-hill). Income from casual activities in agricultural accounts more than 40 per cent of the total income for an average agricultural labourer household followed by permanent agricultural labour and non-farm employment in rural Punjab. South-west region has recorded the highest share of permanent agricultural labour income, while Central plain and Shivalik foot-hill region has recorded the highest share of casual agricultural labour income. The per capita income is the highest in South-west region of Punjab. In all regions, an average household spends higher proportion of total consumption on non-durable items followed by marriages \& other socio-religious ceremonies, services and durable items. There are slightly a few point differences between the expenditure on education and intoxicants among the sampled households.
\end{abstract}

Keywords: Agricultural labourer, Consumption, Income, Per capita income, Rural Punjab

Punjab is one of those Indian states which experienced technological transformation in agriculture during the midsixties. This transformation had been in terms of increased the use of high yielding seed varieties, assured irrigation, fertilisers, insecticides, pesticides and new package of farm machinery. This technological transformation has successfully helped to increase the food grains production in the country. The total food grains production was 55 million tons at the very beginning of the planning era, which increased to 308.65 million tons in 2020-21 (GOI 2021). This new technology has completely replaced traditional mode of production and traditional agriculture was successfully given way to modern and commercial agriculture which result after a short time Punjab became the role model for other states in the country (Singh et al 2016). This leads to change in state's agrarian structure. However, it must be admitted that agrarian structure of Punjab would not have been what it is today if the country had not adopted technological change in encouragement to solve the food grains shortage which it was faced in late 1950's and early 1960's (Sidhu 2005). The agricultural labourers is a large rural worker category, accounting for 30.50 per cent of the total workers, marginally lower than that of India as a whole which is 31.80 per cent (Singh 2000). The share of agricultural labourers in total workforce of the Punjab state has increased from 20.10 per cent in 1971 to 22.16 per cent in 1981 and then to 23.82 per cent in 1991. However, in 2011, this proportion of workers has recorded decline in their percentage to 16.32 (Singh and Singh 2015). Agricultural labourers constitute an important section of the rural community. But they are backward, illiterate, unorganised, and heavily indebted for insufficiency of non-agricultural occupations in villages and find seasonal employment in agriculture. Although agricultural labourers have contributed to Green Revolution, yet they have not benefited, at least in terms of betterment of their conditions (Singh and Toor 2018). Still after the seven decades of adaption of planning for economic development, the position of agricultural labourers and their economic conditions remains unchanged (Singh and Singh 2015). They are unable to fulfill their consumption requirements because of low income level. The social and economic status of agricultural labourers is weak as compared to the other workers and their economic condition has deteriorated remarkably (Chopra 2005). The debt trap is so vicious that more than 80 per cent of agricultural labourers of Punjab are indebted (Kaur et al 2021). The present study is an important attempt to empirically study the economic conditions of agricultural labourer households in rural Punjab.

\section{MATERIAL AND METHODS}

The present study is an empirical analysis of income and consumption pattern among agricultural labourer households in rural Punjab. For the analysis purpose the primary data has collected through a detailed schedule of 
145 sampled households of agricultural labourer category from 6 villages two from each district belonging to three districts (Mansa, Fathegarh Sahib and Hoshiarpur) situated in three well defined agro-climate regions namely South-west region, Central plain region and Shivalik foot-hill region. District Mansa $\left(29.9995^{\circ} \mathrm{N}, 75.3937^{\circ}\right.$ E) selected from South-west region, Fathegarh Sahib district $\left(30.6435^{\circ} \mathrm{N}\right.$, $76.3970^{\circ} \mathrm{E}$ ) from Central Plain region and Hoshiarpur district $\left(31.6479^{\circ} \mathrm{N}, 75.8069^{\circ} \mathrm{E}\right)$ from Shivalik foot-hill region. To carry out the analysis, standard statistical tools like mean values and proportions have been used.

\section{RESULTS AND DISCUSSION}

Region-wise level of household income: In South-west region, an average agricultural labour household earns Rs. 53508, in Shivalik foot-hill region and Central Plain region are Rs. 51744 and Rs. 50845 respectively. The main source of income among agricultural labour households is hiring out casual labour in agricultural, followed by hiring out permanent labour in agricultural, hiring out labour in nonagricultural activities. Income from milk \& milk product rank at fourth positioning, while job salary appears at the fifth position, followed by other sources, self-employment, farm income, sale of livestock and live poultry/egg production in rural Punjab (Table 1).

The region wise comparison shows that the main source of income in South-west region is hiring out permanent labour in agriculture, while in Central plain and Shivalik foot-hill region, the main source of households income from hiring out casual labour in agriculture. In Central plain region and Shivalik foot-hill region hiring out permanent labour in agriculture appears at second place, but in South-west region second place goes to hiring out casual labour in agricultural activities. It is also important to mention here that salary income accounts very small part of household total income across the three regions. The analysis indicates that an average agricultural labour household from South-west region has higher income as compared to Shivalik foot-hill region and Central plain region of rural Punjab.

Pattern of household income: Average household from agricultural labour category earns 41.13 per cent of the total income by hiring out casual labour in agricultural followed by hiring out permanent labour in agricultural (36.76 per cent) and hiring out labour in non-agricultural activities (7.87 per cent). Only 2.57 per cent of the total income comes from job salary. The analysis further reveals that there is variation in the relative share of total income across the three sampled regions. In South-west region, it has recorded the highest share of hiring out permanent labour is agriculture (60.04 per cent), but in Shivalik foot-hill and Central plain region the highest share of the total income comes from hiring out casual labour in agriculture (51.06 and 43.56 per cent) respectively. An average household from agriculture labour category in South-west region gets 29.18 per cent of total income from hiring out casual labour in agriculture, while in Central plain region and Shivalik foot-hill region the relative share of hiring out permanent labour in agriculture are 36.34 per cent and 13.10 per cent respectively. In Shivalik foot-hill region, the relative share of hiring out labour in non-farm activities is the highest (11.87 per cent) as compare to Central plain region and South-west region (10.04 and 1.91 per cent only). The income from job salary is the highest in Shivalik foot-hill region and the lowest in South-west region. There is only Shivalik foot-hill region where an average household earns 3.38 per cent of total income from farm business activity (Table 2). The proportion share of selfemployment source is the highest is Shivalik foot-hill region followed by Central plain region and South-west region. The

Table 1. Region-wise level of mean household income (Rs. per annum)

\begin{tabular}{|c|c|c|c|c|}
\hline Source of income & $\begin{array}{l}\text { Central plain } \\
\text { region }\end{array}$ & $\begin{array}{l}\text { Shivalik foot-hill } \\
\text { region }\end{array}$ & South-west region & $\begin{array}{l}\text { All sampled } \\
\text { households }\end{array}$ \\
\hline Farm business & 0 & 1752 & 0 & 584 \\
\hline Milk and milk products & 1560 & 2107 & 1757 & 1808 \\
\hline Live poultry/eggs production & 276 & 314 & 127 & 239 \\
\hline Livestock/ livestock products & 384 & 569 & 281 & 411 \\
\hline Hiring out permanent labour in agriculture & 18474 & 6780 & 32129 & 19127 \\
\hline Hiring out casual labour in agriculture & 22149 & 26421 & 15614 & 21395 \\
\hline Hiring out labour in non-agricultural activities & 5134 & 6144 & 1018 & 4098 \\
\hline Salaries & 769 & 2613 & 641 & 1341 \\
\hline Self-employment & 531 & 1499 & 419 & 816 \\
\hline Other sources & 1568 & 3545 & 1522 & 2212 \\
\hline Total & 50845 & 51744 & 53508 & 52031 \\
\hline
\end{tabular}

Source: Primary field survey 
relative share of other sources, pensions, sale of manure, live poultry/ livestock get very low proportion of the total household income among the agricultural households in rural Punjab. The analysis reveals that an agricultural labourer household in three regions of rural Punjab supplements their income with different activities.

Region-wise per capita income: Per capita income among an average household of agricultural labourer category is Rs. 12125 in rural Punjab (Table 3). An agricultural labour household in South-west region earns the highest (Rs. 12588) per capita annually and the lowest in Central plain region (Rs. 10314) of rural Punjab.

Region-wise household consumption expenditure: An average household from agricultural labourer category spends the highest amount on non-durables items (Rs. 43454) of consumption expenditure, followed by marriages \& other socio religious ceremonies (Rs. 8824), services (Rs. 6002) and durable items (Rs. 4060). The study reveals that out of total consumption expenditure on non-durables, an average household spends higher amount on food grain (Rs. 16949), followed by milk\& milk products (Rs. 8220) and intoxicant \& drugs (Rs. 3842). The other important components of non-durables items include teas leaves, fuel \& light, clothing \& bedding, footwear, LPG, edible oils etc. As far as consumption expenditure on durable items is concerned, the highest amount spends on house construction/major repair (Rs. 1764). Out of total consumption expenditure on different kinds of services, an average household spends the highest amount on healthcare, followed by conveyance, education, telephone communication, entertainment and so on. The analysis reveals that an average household spends less on education as compare to telephone communication services (Table 4).

An average household from agricultural labourer household category in South-west region spends the highest amount (Rs. 67804) on consumption expenditure, followed by Central plain region (Rs. 61474) and Shivalik foot-hill region (Rs. 60644). In South-west region an average households spends the highest amount on non-durable items (Rs. 48572), followed by Central plain region (Rs. 46655) and Shivalik foothill region (Rs. 42625). In case of durable items of consumption expenditure, an average household from South-

Table 2. Region-wise pattern of household income (Percentage)

\begin{tabular}{|c|c|c|c|c|}
\hline Source of income & $\begin{array}{c}\text { Central plain } \\
\text { region }\end{array}$ & $\begin{array}{l}\text { Shivalik foot-hill } \\
\text { region }\end{array}$ & South-west region & $\begin{array}{l}\text { All sampled } \\
\text { households }\end{array}$ \\
\hline Farm business & 0.00 & 3.38 & 0.00 & 1.12 \\
\hline Milk and milk products & 3.06 & 4.08 & 3.28 & 3.47 \\
\hline Live poultry/eggs production & 0.55 & 0.61 & 0.24 & 0.46 \\
\hline Livestock/ livestock products & 0.76 & 1.09 & 0.53 & 0.78 \\
\hline Hiring out permanent labour in agriculture & 36.34 & 13.10 & 60.04 & 36.76 \\
\hline Hiring out casual labour in agriculture & 43.56 & 51.06 & 29.18 & 41.13 \\
\hline Hiring out labour in non-agricultural activities & 10.09 & 11.87 & 1.91 & 7.87 \\
\hline Salaries & 1.51 & 5.05 & 1.19 & 2.57 \\
\hline Self-employment & 1.04 & 2.89 & 0.78 & 1.57 \\
\hline Other sources & 3.09 & 6.87 & 2.85 & 4.26 \\
\hline Total & 100.00 & 100.00 & 100.00 & 100.00 \\
\hline
\end{tabular}

Source: Primary field survey

Table 3. Region-wise per capita value of household income (Rs. per annum)

\begin{tabular}{lcccc}
\hline Source of income & $\begin{array}{c}\text { Central plain } \\
\text { region }\end{array}$ & $\begin{array}{c}\text { Shivalik foot-hill } \\
\text { region }\end{array}$ & $\begin{array}{c}\text { South-west region } \\
\text { All sampled } \\
\text { households }\end{array}$ \\
\hline Farm business & 0 & 404 & 0 & 136 \\
Milk and milk products & 316 & 486 & 416 & 421 \\
Live poultry/eggs production & 56 & 72 & 30 & 55 \\
Livestock/ livestock products & 78 & 131 & 66 & 96 \\
Hiring out permanent labour in agriculture & 3748 & 1564 & 3620 & 4459 \\
Hiring out casual labour in agriculture & 4494 & 6097 & 241 & 4987 \\
Hiring out labour in non-agricultural activities & 1041 & 1418 & 0 & 955 \\
Salaries & 156 & 603 & 152 & 312 \\
Pensions & 94 & 197 & 73 & 126 \\
Self-employment & 107 & 346 & 439 & 190 \\
Other sources & 318 & 816 & 12588 & 514 \\
Total & 10314 & 11937 & & 12125 \\
\hline
\end{tabular}


Table 4. Region-wise level of household consumption expenditure (Rs. per annum)

\begin{tabular}{|c|c|c|c|c|}
\hline Items of consumption & $\begin{array}{l}\text { Central plain } \\
\text { region }\end{array}$ & $\begin{array}{l}\text { Shivalik foot-hill } \\
\text { region }\end{array}$ & South-west region & $\begin{array}{l}\text { All sampled } \\
\text { households }\end{array}$ \\
\hline \multicolumn{5}{|l|}{ Non-Durables } \\
\hline Food grains & 17329 & 16458 & 17084 & 16949 \\
\hline i. Cereals & 15842 & 15191 & 15755 & 15539 \\
\hline ii. Pulses & 1487 & 1267 & 1329 & 1410 \\
\hline Condiments and spices & 987 & 770 & 997 & 940 \\
\hline Fruits & 326 & 412 & 210 & 279 \\
\hline Vegetables & 1418 & 1310 & 1363 & 1259 \\
\hline Milk and Milk products & 8816 & 8135 & 9196 & 8220 \\
\hline Edible oils & 1289 & 976 & 1512 & 1042 \\
\hline Sugarcane products & 3016 & 2663 & 3519 & 3071 \\
\hline Meat, fish and eggs & 289 & 175 & 122 & 197 \\
\hline Tea leaves & 1708 & 1243 & 2041 & 1664 \\
\hline Biscuits/bread and sweets & 672 & 503 & 515 & 563 \\
\hline Pickles & 228 & 127 & 278 & 211 \\
\hline Intoxicants and Drugs & 4065 & 4289 & 6171 & 3842 \\
\hline Fuel and Light & 783 & 727 & 590 & 700 \\
\hline Clothing and Bedding & 2985 & 2529 & 2651 & 2168 \\
\hline Soaps and Detergents & 937 & 794 & 874 & 869 \\
\hline Footwear & 1536 & 1273 & 1336 & 1272 \\
\hline LPG & 148 & 66 & 33 & 82 \\
\hline Others & 123 & 175 & 81 & 126 \\
\hline Sub-total & 46655 & 42625 & 48572 & 43454 \\
\hline \multicolumn{5}{|l|}{ Durables } \\
\hline House construction/repairs & 1363 & 1772 & 1743 & 1764 \\
\hline Radio/TV/VCR/Tape records/CD & 623 & 266 & 271 & 387 \\
\hline Watches/Clocks & 80 & 6 & 474 & 187 \\
\hline Electric fans/cooler & 349 & 370 & 447 & 388 \\
\hline Sewing machine & 104 & 84 & 88 & 92 \\
\hline Furniture & 24 & 30 & 47 & 34 \\
\hline Utensils & 135 & 97 & 122 & 118 \\
\hline Scooter/Motorcycles & 252 & 333 & 420 & 410 \\
\hline Bicycles & 351 & 297 & 535 & 405 \\
\hline Others & 116 & 374 & 297 & 275 \\
\hline Sub-total & 3397 & 3629 & 4444 & 4060 \\
\hline \multicolumn{5}{|l|}{ Services } \\
\hline Education & 573 & 527 & 379 & 565 \\
\hline Healthcare & 2443 & 2014 & 4123 & 3093 \\
\hline Conveyance & 980 & 1049 & 1322 & 1126 \\
\hline Telephone/ mobile & 808 & 736 & 902 & 823 \\
\hline Entertainment & 111 & 248 & 135 & 165 \\
\hline Others & 24 & 37 & 175 & 230 \\
\hline Sub-total & 4939 & 4611 & 7036 & 6002 \\
\hline Marriages and other Socio-religious ceremonies & 6483 & 9779 & 7752 & 8824 \\
\hline Total & 61474 & 60644 & 67804 & 62340 \\
\hline
\end{tabular}

Source: Primary field survey 
Table 5. Region-wise pattern of household consumption expenditure (Percentage)

\begin{tabular}{|c|c|c|c|c|}
\hline Items of consumption & $\begin{array}{l}\text { Central plain } \\
\text { region }\end{array}$ & $\begin{array}{l}\text { Shivalik foot-hill } \\
\text { region }\end{array}$ & South-west region & $\begin{array}{l}\text { All sampled } \\
\text { households }\end{array}$ \\
\hline \multicolumn{5}{|l|}{ Non-Durables } \\
\hline Food grains & 28.19 & 27.13 & 25.19 & 27.18 \\
\hline i. Cereals & 25.77 & 25.04 & 23.23 & 24.92 \\
\hline ii. Pulses & 2.42 & 2.09 & 1.96 & 2.26 \\
\hline Condiments and spices & 1.60 & 1.27 & 1.47 & 1.51 \\
\hline Fruits & 0.54 & 0.68 & 0.31 & 0.45 \\
\hline Vegetables & 2.30 & 2.16 & 2.01 & 2.02 \\
\hline Milk and Milk products & 14.29 & 13.41 & 13.56 & 13.18 \\
\hline Edible oils & 2.09 & 1.61 & 2.23 & 1.67 \\
\hline Sugarcane products & 4.89 & 4.39 & 5.19 & 4.92 \\
\hline Meat, fish and eggs & 0.48 & 0.29 & 0.18 & 0.32 \\
\hline Tea leaves & 2.78 & 2.05 & 3.01 & 2.67 \\
\hline Biscuits/bread and sweets & 1.09 & 0.83 & 0.76 & 0.90 \\
\hline Pickles & 0.38 & 0.21 & 0.41 & 0.34 \\
\hline Intoxicants and Drugs & 6.59 & 7.07 & 9.10 & 6.16 \\
\hline Fuel and Light & 1.27 & 1.20 & 0.87 & 1.13 \\
\hline Clothing and Bedding & 4.87 & 4.17 & 3.91 & 3.48 \\
\hline Soaps and Detergents & 1.58 & 1.32 & 1.29 & 1.39 \\
\hline Footwear & 2.49 & 2.10 & 1.97 & 2.05 \\
\hline LPG & 0.25 & 0.11 & 0.05 & 0.13 \\
\hline Others & 0.21 & 0.29 & 0.12 & 0.20 \\
\hline Sub-total & 75.89 & 70.29 & 71.64 & 69.70 \\
\hline \multicolumn{5}{|l|}{ Durables } \\
\hline House construction/repairs & 2.21 & 2.92 & 2.57 & 2.83 \\
\hline Radio/TV/VCR/Tape records/CD & 1.01 & 0.44 & 0.40 & 0.62 \\
\hline Watches/Clocks & 0.13 & 0.01 & 0.70 & 0.30 \\
\hline Electric fans/cooler & 0.89 & 0.61 & 0.66 & 0.62 \\
\hline Sewing machine & 0.17 & 0.14 & 0.13 & 0.15 \\
\hline Furniture & 0.04 & 0.05 & 0.07 & 0.05 \\
\hline Utensils & 0.22 & 0.16 & 0.18 & 0.19 \\
\hline Scooter/Motorcycles & 0.41 & 0.55 & 0.62 & 0.66 \\
\hline Bicycles & 0.57 & 0.49 & 0.79 & 0.65 \\
\hline Others & 0.19 & 0.62 & 0.44 & 0.44 \\
\hline Sub-total & 5.82 & 5.98 & 6.55 & 6.52 \\
\hline \multicolumn{5}{|l|}{ Services } \\
\hline Education & 0.93 & 0.87 & 0.56 & 0.91 \\
\hline Healthcare & 3.96 & 3.32 & 6.08 & 4.96 \\
\hline Conveyance & 1.59 & 1.73 & 1.95 & 1.80 \\
\hline Telephone/ mobile & 1.31 & 1.21 & 1.33 & 1.32 \\
\hline Entertainment & 0.18 & 0.41 & 0.20 & 0.26 \\
\hline Others & 0.04 & 0.06 & 0.26 & 0.38 \\
\hline Sub-total & 8.04 & 7.61 & 10.38 & 9.63 \\
\hline Marriages and other Socio-religious ceremonies & 10.55 & 16.12 & 11.43 & 14.15 \\
\hline Total & 100.00 & 100.00 & 100.00 & 100.00 \\
\hline
\end{tabular}


Table 6. Per capita value of household consumption expenditure (Rs. per Annum)

\begin{tabular}{|c|c|c|c|c|}
\hline Items of consumption & $\begin{array}{l}\text { Central plain } \\
\text { region }\end{array}$ & $\begin{array}{l}\text { Shivalik foot-hill } \\
\text { region }\end{array}$ & South-west region & $\begin{array}{l}\text { All sampled } \\
\text { households }\end{array}$ \\
\hline \multicolumn{5}{|l|}{ Non-Durables } \\
\hline Food grains & 3516 & 3798 & 4052 & 3951 \\
\hline i. Cereals & 3214 & 3505 & 3736 & 3623 \\
\hline ii. Pulses & 302 & 293 & 316 & 328 \\
\hline Condiments and spices & 200 & 177 & 236 & 219 \\
\hline Fruits & 66 & 95 & 49 & 65 \\
\hline Vegetables & 287 & 302 & 323 & 293 \\
\hline Milk and Milk products & 1788 & 1877 & 2181 & 1916 \\
\hline Edible oils & 261 & 225 & 358 & 242 \\
\hline Sugarcane products & 612 & 614 & 834 & 715 \\
\hline Meat, fish and eggs & 58 & 40 & 28 & 46 \\
\hline Tea leaves & 346 & 287 & 484 & 388 \\
\hline Biscuits/bread and sweets & 136 & 116 & 122 & 131 \\
\hline Pickles & 46 & 29 & 65 & 49 \\
\hline Intoxicants and drugs & 824 & 989 & 1463 & 895 \\
\hline Fuel and light & 158 & 168 & 139 & 163 \\
\hline Clothing and bedding & 605 & 583 & 628 & 505 \\
\hline Soaps and detergents & 190 & 183 & 207 & 202 \\
\hline Footwear & 311 & 294 & 316 & 296 \\
\hline LPG & 30 & 15 & 8 & 19 \\
\hline Others & 25 & 40 & 19 & 29 \\
\hline Sub-total & 9459 & 9832 & 11512 & 10124 \\
\hline \multicolumn{5}{|l|}{ Durables } \\
\hline House construction/repairs & 276 & 409 & 413 & 411 \\
\hline Radio/TV/VCR/Tape records/CD & 126 & 61 & 64 & 90 \\
\hline Watches/Clocks & 16 & 1 & 112 & 43 \\
\hline Electric fans/cooler & 70 & 85 & 106 & 90 \\
\hline Sewing machine & 21 & 19 & 20 & 21 \\
\hline Furniture & 5 & 7 & 11 & 7 \\
\hline Utensils & 27 & 22 & 28 & 27 \\
\hline Scooter/Motorcycles & 51 & 77 & 99 & 95 \\
\hline Bicycles & 71 & 68 & 127 & 94 \\
\hline Others & 22 & 85 & 69 & 63 \\
\hline Sub-total & 685 & 834 & 1049 & 941 \\
\hline \multicolumn{5}{|l|}{ Services } \\
\hline Education & 116 & 121 & 90 & 131 \\
\hline Healthcare & 495 & 464 & 978 & 721 \\
\hline Conveyance & 199 & 242 & 313 & 262 \\
\hline Telephone/ mobile & 163 & 169 & 213 & 191 \\
\hline Entertainment & 22 & 57 & 32 & 38 \\
\hline Others & 4 & 8 & 41 & 53 \\
\hline Sub-total & 999 & 1061 & 1669 & 1396 \\
\hline Marriages and other Socio-religious ceremonies & 1315 & 2256 & 1838 & 2057 \\
\hline Total & 12458 & 13983 & 16066 & 14518 \\
\hline
\end{tabular}

Source: Primary field survey 
west region spends the highest amount, followed by Shivalik foot-hill region and Central plain region. In South-west region, an average household from agricultural labourer category spends the highest amount on different types of services as compared to other two regions as Central plain and Shivalik foot-hill region. In Shivalik foot-hill region, an average household spends the highest (Rs.9779) on marriages \& other socio-religious ceremonies, followed by South-west region (Rs. 7752) and Central plain region (Rs. 6483).

Region-wise pattern of household consumption expenditure: The relative share of household consumption expenditure has recorded the highest share of the total consumption expenditure spends on non-durable items of consumption expenditure (69.70 per cent). In Central plain region, the highest share (75.89 per cent) spends on nondurable items, while the lowest (70.29 per cent) in Shivalik foot-hill region spends on non-durable items of consumption. The analysis has found that the expenditure on marriages \& other socio-religious ceremonies appears the second place where the relative share is the highest (16.12 per cent) in Shivalik foot-hill region, followed by South-west region (11.43 per cent) and Central plain region 10.55 per cent of the total consumption expenditure. An average household spends 14.15 per cent on marriages \& other socio-religious ceremonies of consumption expenditure (Table 5).

The proportion of consumption expenditure on services is the highest (10.38 per cent) in South-west region, followed by Central plain region (8.04 per cent) and Shivalik foot-hill region (7.61 per cent) while in all sampled regions an average household spends 9.63 per cent on different kinds of services. The highest percentage consumption expenditure appears on healthcare services in three sampled regions under study. As far as consumption expenditure on durable items is concerned, it has recorded 6.52 per cent of the total consumption. In South-west region, an average household spends higher proportion on durable items, followed by Shivalik foot-hill region and Central plain region.

Per capita household consumption expenditure: The analysis has found that an average household from agricultural labourer household category in rural Punjab consumer annually Rs. 14518 per capita on different items of consumption. Further, the study reveals that an average household from South-west region has the highest per capita consumption, while the lowest in Central plain region (Table $6)$.

\section{CONCLUSIONS}

The present study analysed that the main source of income among agricultural labourer households is hiring out causal labour in agriculture. But region-wise analysis reveals that an average household in South-west region earns the highest proportion of total income from hiring out permanent labour in agriculture, while in Shivalik foot-hill region and Central plain region, the higher relative share of total incomes comes from hiring out casual labour in agriculture. An average household spends large proportion of their income on non-durables items of consumption expenditure, followed by marriages \& other socio-religious ceremonies, services and durables. The present level of income of agricultural labourer households in rural Punjab is not enough to support their daily consumption requirements. The foregoing analysis shows that there is declining permanent labour and rise in casualization of labour in agricultural activities in rural Punjab. To meet their basis needs, they are forced to borrow from non-institutional agencies and they fell in debt trap and their debt continued to increase day by day. The government should make a strong policy regarding subsidiary occupations and provide financial support at reasonable interest rate. The analysis has found the dairying is one of the main sources of household's income in rural Punjab, but the price of milk is very low. So the Government should come forward with appropriate policy in this regard to increase their level of income. To uplift the poor non-farming households in rural areas, there is a strong need to establish agro-based industries in rural areas. These households can get employment in these industries for a reasonable number of days and at decent wage rate. The proper implementation of MGNREGA would be milestone helpful to overcome the problems of agricultural labourer households.

\section{REFERENCES}

Chopra S 2005. The problems of agricultural labourer and neo-liberal reforms. People's Democracy 29(15). http://archives. peoplesdemocracy.in/2005/0410/04102005_suneet.htm

Government of India. Economic Survey of India (Various Issues). Oxford University Press, New Delhi.

Kaur R, Singh G and Jain N 2021. Inter-regional analysis of indebtedness among scheduled caste households in rural Punjab. Indian Journal of Ecology 48(2): 569-574.

Sidhu HS 2005. Production condition on contemporary Punjab. Journal of Punjab Studies 12(2): 197-217.

Singh G and Singh G 2015. Deplorable conditions of agricultural labourers in rural Punjab. Journal of Economic \& Social Development 11(2): 44-55.

Singh S and Toor JS 2018. Level of living of non-farming households in South-west region of Punjab, pp 45-62. In: RS Gill (eds) Contemporary economic issues in India. Twentyfirst century publications, Patiala, India.

Singh S, Toor JS and Tiwana BS 2016. Structure of assets among households in rural Punjab: An empirical analysis. Indian Journal of Economic and Development 12(2): 255-264.

Singh Sukhpal 2000. Crisis in Punjab agricultural. Economic and Political Weekly 35(4): 1889-1892. 